\title{
Religion Caste Inside Sembah Catur on Serat Wedhatama, Pupuh Gambuh made by KGPAA Mangkunegara IV
}

\author{
Rudi Permono Putro ${ }^{1}$, Muhammad Rohmadi ${ }^{2}$, Ani Rakhmawati ${ }^{3}$, and Kundharu \\ Saddhono 4 \\ \{rudi@student.uns.ac.id ${ }^{1}$,rohmadi_dbe@yahoo.com²,a_rakhmaw@fkip.uns.ac.id ${ }^{3}$, \\ kundharu_s@staff.uns.ac.id $\left.{ }^{4}\right\}$ \\ 1,2,3 Universitas Sebelas Maret, Surakarta, Indonesia
}

\begin{abstract}
The lack of assessment of the meaning inlearning macapat songs at school makes the value contained in pupuh Gambuh Serat Wedhatama as a teaching material for macapat song cannot be conveyed.This study aims to identify and describe the Islamic religious caste contained in macapat song. Macapat song is an indigenous Javanese drum that mostly contains the virtue of life. The function and role of macapat songs are as the educational means to instill noble cultural values and religious values into society. The source of this research is Serat Wedhatama pupuh Gambuh song made by KGPAA Mangkunegara IV. The religious caste in this study is interpreted through four levels of Islamic spiritual experience. The research employed semiotic analysis of Riffaterre through hermeneutic codes. The results of the study find four religious castes contained in Serat Wedhatama pupuh Gambuh. Those religious caste include: syariat (Shari'a), tarekat (way), hakekat (substance), and makrifat (knowledge). The four levels of the human group are characterized by the way of worship, purification, and the degree of intimacy with God. The results of this research are expected to enrich the repertoire of studying meaning in macapat songs particularly in Gambuh song in Serat Wedhatama.
\end{abstract}

Keywords: Islamic Religious Caste, Gambuh song, Serat Wedhatama, Semiotics, Hermeneutics

\section{INTRODUCTION}

Belief in the One and Only God, as the first principle in Pancasila implies that Indonesia is a country that ethically and morally acknowledges the existence of God [6]. This represents the devotion value which means that every religious person must carry out His commands and leave His prohibitions. Religious values can be obtained by humans through religious books or 
the results of comprehending a literary work [15].These religious values are usually integrated with the pitutur luhur (noble stories) of Javanese literature that are often manifested and included in Javanese cultural arts. Pitutur luhur is delivered in writing, spoken language, and symbolic language/ demonstration, for instance, using proverbs, macapat songs, fairy tales, tutur tinular, traditional expressions, conveyed by the movements of body parts/ anepa, and through meaningful images [20]. Pitutur luhur in Javanese literature is piwulang(teaching) literary work. Pitutur luhur of Javanese people contains the teaching of the life virtues [7]. All literatures that are spread in the community contain pitutur luhur and teachings of the virtues of life in society. So that people always remember and accept that life in this world is just stopping byto drink; therefore, they must be vigilant and always behave in a goodway to be a human who is perfect for the love to others [21].

This research employed semiotics analysis of Riffaterre through hermeunetic codes as one of the semiotics theories or the discipline of the meaning of decision in a code. The role of semiotics as a study of signs which plays an important role in reading the codes put by the author in a literature to find out the code that is left [13]. According to Riffaterre, to produce meaning in literary works, especially poetry, there are four things that must be considered which are related to the analysis of signs, namely indirect expressions in poetry, heuristic readings (definitions) and hermeneutics (meanings), matrix searches, and hypograms (showing intertextual relationships) [9]. The semiotics theory of Riffatere through hermeneutic codes is very suitable to be used to analyze a poem [16]. Gambuh song as one of the types of macapat songs is a traditional Javanese poetry that has Javanese literary rules or standards. The type of poem is bound by a standard convention in the form of guru gatra or number of lines in the paragraph, guru wilangan or number of syllables in the line and guru lagu or syllable sound at the end of the line [22].

Gambuh comes from the word jumbuh which means united. Gambuh is a representation of humans who reach the stage of marriage and build life together with their legal partners on behalf of the religion and country which mutually committed to live a new life as husband and wife in the household, teachings to the younger generation about how to establish human relations, advice on building the brotherhood, tolerance, and togetherness as social beings [22]. Gambuh song is one of macapat song types found in Serat Wedhatama which contains Islamic religious values. Religious values are attitudes and behaviors that are obedient in carrying out the teachings of the religion they adhere to, tolerant of the conduct of worship of other religions, and living in harmony with those of other religions [10]

The religious values contained in a literary work has an aim to make the connoisseurs of the work get inner reflections in life that come from religious values. Activities that have a background in religious values will have a positive impact on one's social attitudes [2]. Serat Wedhatama pupuh Gambuh paragraph 1 describes four levels (four castes) of human groups in reaching devotion of God including sembah raga/worship of physic (body), sembah cipta/worship of thinking (logic/thought), sembah jiwa/worship of soul (soul), and sembah rasa/worship of feeling (heart). Worship in this context is interpreted as worship to God. Furthermore, those four levels of worship in Serat Wedhatama have relevance to the Islamic Sufism level. As a result, the study of the sembah catur (four worships) was needed to internalize the value of Islamic religion in the society. This research contributes to more detailed, in-depth, and comprehensive understanding for the readers especially high school students that Sembah Catur contained in Serat Wedhatama pupuh Gambuh is the Islamic religious castes. Religious castes in this study is comprehended by four levels of Islamic spiritual experiences. Those religious castes encompass: shari'a, tarekat, hakikat, and makrifat. 


\section{METHOD}

This research used content analysis research method, which is a form of research that aims to generate objective and systematic descriptions of the content and meaning contained in communication media [18]. There are at least 6 processes for collecting data and analysis from this study. The process is as follows: unitizing, sampling, recording / coding, reducing data to manageable representation, abductively inferring contextual phenomena, and narrating the answer to the research question.

Basically, unitizing, sampling, recording, and reducing data to manageable representation areunits of process which is called as data making [8]. Unitizing is the process of classifying parts of documents systematically according to the desired classification form. Sampling is the process of taking quotes from a text or document where the quotations can represent the population of data to be analyzed. Recording/coding is the process of converting text to be easily understood and analyzed. Abductively inferring contextual phenomena is a process of analysis carried out by the researchers in accordance with the appropriate context contained in the document itself. Narrating the answer to the research question is the process of informing the results of the analysis; hence it becomes easy to comprehend a research report [17]. After all data making processes were carried out, researchers then analyzed the data obtained using qualitative approach.

\section{RESULT AND DISCUSSION}

Serat Wedhatama pupuh Gambuh which is around 160-170 years old by KGPAA Mangkunegara IV, consists of 35 pupuh [5]. The literature is included in cultural, linguistic, religious-based repertoires as objects for teaching and learning in school [19]. As an object of teaching material for macapat songs, pupuh Gambuh represents four classes of people (castes) based on their level of devotion as proven from their worship (Sembah Catur). It explains how Javanese Islamic spiritual is full of Sufism (Sufi Islam), which emphasizes heavy spiritual processes such as undergoing mujahadah or heavy spiritual practices (spiritual practice, dhikr, fasting, etc.). The teachings of Sufism were developed from Islamic writers including KGPAA Mangkunegara IV [23].

The meaning of song in pupuh Gambuh uses Riffaterre's hermeneutic code analysis. Riffateree's hermeneutic code analysis is suitable for analyzing a poem. Poetry always tells something indirectly by hiding it into a sign [16]. Macapat songs are included into traditional poetry because they have writing rules, even though the rules are the standard ones. The first process of data collection is unification. The following is a table of the division of Islamic religious levels contained in pupuh Gambuh Serat Wedhatama:

Table 1. Sembah Catur structural in Serat Wedhatama pupuh Gambuh

\begin{tabular}{lll}
\hline No & Sembah Catur & Total \\
\hline I & Sembah raga & 10 \\
II & Sembah cipta & 5 \\
III & Sembah jiwa & 7 \\
IV & Sembah Rasa & 13
\end{tabular}

Pupuh Gambuh pada 1 (paragraph 1), Serat Wedatama by KGPAA Sri Mangkunegara IV:

Terjemahan dalam Bahasa Indonesia:

Sekarang saya menasihati,

Empat sembah supaya engkau pahami,

Pertama, raga, cipta, jiwa, rasa, nak,

Di situ bila tercapai,

Itulah anugrah dari Yang Maha Melihat. 
Samengko ingsun tutur,

Sembah catur supaya lumuntur,

Dhihin raga, cipta, jiwa, rasa, kaki,

Ing kono lamun tinemu,

Tandha nugrahaning Manon.

Translation in English

Now I give advice

Four worships tomake you understand

First, physic, thinking, soul, feeling,

If achieved

It becomes the grace from the All-Seeing

The above-mentioned excerpt is pupuh Gambuh pada 1 (paragraph 1), the second process of collecting data wascollecting the sampling as the representative of the data population of all the songs in pupuh Gambuh that would be analyzed. The first line states:Samengko ingsun tutur ('now I say ') has a hermeneutic code from the author who conveyed the message that it was time for me (the author said) to give advice. Advice is interpreted by the message of kindness with the pitutur (advice). The word tutur in Javanese is used to refer to the words of adults, namely those who have experience in sailing through the ocean of life. The term "lebda ing pitutur" is often used to refer to people who are appropriate to give such advice. In Javanese culture, elderly people are highly valued and respected, not in the material element but rather in their pitutur which can be accepted by their blessings and advice. Tiyang Sepuh is a person who is expected to have prayers and blessings for every occasion and important need. They have the role to bequeath (lumuntur) wisdom and virtue of life through piwulang ('good teachings'), wewarah ('understanding') and pitutur ('advice'). That suits to the main objective of educational process which is teaching the values [1].The hermeneutic analysis of the four Islamic religious castes in the concept of Sembah Catur Serat Wedhatama is presented below:

\subsection{Islamic religious castes in Gambuh Serat Wedhatama}

Afterwards, the second line states: Sembah catur supaya lumuntur ('four kinds of worship to be bequeathed / understood') has a hermeneutic code of 'Four worships so you understand'. LiteraryText, especially poetry/traditional poetry shows that each word can refer to objects, representamen, and interpretan by which the meaning of a poem depends on the words that are more dominant for the readers un showing themselves as signs [14].In the line of this song, the author explains that in worshipping God has four levels that must be understood by the people. Those four levels in the Serat Wedhatama pupuh Gambuh are described through four kinds of worship. In the next line is explained Dhihin raga, cipta, jiwa, rasa, kaki which mean sembah raga/worship of physic (body), sembah cipta/worship of thinking (logic/thought), sembah jiwa/worship of soul (soul), and sembah rasa/worship of feeling (heart). The concept of Sembah Catur is relevant to the spiritual aspects through various religious rules including three sectors, namely faith, Islam, and Ihsan, or in other languages, namely Shari'a, tarekat, hakikat and makrifat, to prepare sufficient provisions for the soul who will experience true life forever after the humans die [11].

\subsubsection{Sembah Raga/Shari'a}

The first worship is sembah raga ('body, body parts). It shows that the first level in Islamic religious caste is worship or in the term of Islamic Sufism called shari'a. Shari'a is a 
law or regulation that comes from Allah SWT, both through the Qur'an, the Sunnah of His Prophet, as well as from both in the form of Ijma and Qiyas. If the rule does not come from Allah SWT, then it is not called Shari'a [4]. Islamic law in Islam is characterized by the obedience of the peopleto worship in accordance with the rules that come from his Lord. Worship is the obligatory in the Islamic Shari'ah that is mostly symbolized by the movement of the body, the worship of God manifested by physical movement, such as the person who is doing the prayer that there is a procedure for the movements that is standard. The procedures or rules of Sembah Raga are described in the Serat Wedhatama pupuh Gambuh in pada 1 (paragraph 2).

Before performing sembah raga / physical rituals such as prayer five times, the rules that must be previously done first by which one of them is purification. In Serat Wedhatama of paragraph 2 described the procedure of purification, sesucine asarana saking (purification uses water'). The conditions for performing salat are to be washed with water. The concept of purification is relevant to the teachings of purification in Islam called thaharah. Thaharah literally means clean and purified from all dirt, both the visible one such as filth and the invisibleone such as disgrace. According to the term from fuqaha 'or the jurists of Thaharah, it means to cleanse themselves from impurity and filth, like bathing and tayammum (purification uses dust) [12].

Material characteristics of the body can only be cleaned only by material too. Kang wus lumrah limang wektu ("what is common isobliged to do five times"). The Hermeneutic Code means that 'the obligatory is the five times'. The obligatory sembah ragais five times, namely the obligatory to perform prayer that must be done by everyone. Other than the obligation of five times, there are many recommended optional salat/prayers to a Muslim according to their abilities and circumstances. It is not mandatory and is optional, according to the situation, conditions and concessions of each person. Wantu of wataking weweton ('periodic, characterized by rules/rukun'). The hermeneutic code means "to obey the rules of time and rukun". The five time obligatory prayers cannot be done randomly because there is a due timeand rukun/rules, as well as the conditions for doing so. The time must be entered according to each of the obligatory prayers, which are Subuh prayer which is after dawn, Dhuhur prayer which is when the sun risen, Ashar prayer which is before the sun goes down, Maghrib prayer which is after sunset, Isya 'prayer which is in evening.

\subsubsection{Sembah Cipta/logical thinking}

The second religious caste is sembahcipta that has the hermeneutic code to mark the 'thinking' or in the term of Islamic Sufism called tarekat. Performing sembah raga must be accompanied by sembah cipta by focusing to what is worshipped (God). The thinking is merely obeying the majesty and divinity of God.

\subsubsection{Sembah Jiwa/Jiwa}

The third religious caste is sembah jiwa that has a hermeneutic code that signifies 'soul' as a wishful thinking producer or in the term of Islamic Sufism called hakikat, hence sembah jiwa must include the concentration of all wishful thinking only to Allah alone. It is inappropriate if you are praying yet you are wondering the baskets of rice in the kitchen, as an example.

\subsubsection{Sembah Rasa/Hati}

The fourth religious caste is sembah rasa that has a hermeneutic code that signifying 'this is the highest peak of worship or in the term of Islamic Sufism called makrifat'. This level is the final destinantion or the peak if the highest achievement from the highest Islamic religion level (tasawuf) [3].All feelings come from the heart, so sembah rasa is an effort to purify the 
heart. Accustomed to calm down the heart, tuma'ninah, to face the All-Seeing. In religious language, it is called ihsan. Those are the four types of worship that must always be done simultaneously in a set of movements.

In the last line of the first paragraph in pupuh Gambuh is Ing kono lamun tinemu ('That it is found there'). The hermeunetic code has the meaning that 'If Tandha (sign) nugrahaning (to get grace) Manon (All-Seeing) are achieved. That is the grace of the All-Seing. In a set of four prayers, if it can be done, it will meet with the rosing panembah, which is the submission of body, mind, soul and feeling to the Divine God. Therefore, humans can only try to achieve it through a series of practices that have been determined, while the achievement of the goal is merely a gift from the All-Seeing.

Sesucine (purifying) asarana (using) saking (from) warih (water). Purifying uses water. The conditions for performing prayer are washing with water. This is according to the nature of the body which is material in nature, which can only be cleaned with material too [24]. Kang (who) wus lumrah (already common, obligatory) limang (five) wektu (time). What is obligatory is five times. The obligatory exercise is five times, namely the obligatory prayer that must be done by everyone. Other than the obligation of five times, there are many recommended optional prayers to a Muslim according to their abilities and circumstances. It is not mandatory and is optional, according to the situation, conditions and flexibility of each person. Wantu (periodic) wataking (nature) authority (rules, rukun). Having the characteristic according to the rules of time and rukun. The five time obligatory prayers cannot be done randomly because there is a due time and rukun/rules, as well as the conditions for doing so. The time must be entered according to each of the obligatory prayers, which are Subuh prayer which is after dawn, Dhuhur prayer which is when the sun risen, Ashar prayer which is before the sun goes down, Maghrib prayer which is after sunset, Isya 'prayer which is in evening.

\section{CONCLUSION}

This research has come to the conclusion that there are four worshipcastes in Serat Wedhatama pupuh Gambuh (sembah raga, sembah cipta, sembah jiwa, sembah rasa), in accordance with the four levels in Islamic tasawuf that is syariat (Shari'a), tarekat (way),hakekat (substance), and makrifat (knowledge). The study also affirms the relevance of the teachings contained in the Serat Wedhatama pupuh Gambuh with Islamic teachings. In a nutshell, the Serat can be used as a reference to values and community life guidelines in the midst of secularization of culture and religion.

\section{REFERENCES}

[1] N. A. Al-Mosa. "Role of Social Networks in Developing Religious and Social Values of the Students of the World Islamic Sciences \& Education University". International Education Studies, Vol. 8, No. 9, 126-137, 2015.

[2] C. H. W. Cheung, K. J. Kennedy, C. H. Leung, and M. T. Hue. "Religious Engagement and Attitudes to The Role of Religion in Society: Their Effect on Civic and Social Values in An Asian Context". British Journal of Religious Education, Vol. 40, No. 2, pp. 158-168, 2018.

[3] S. Endraswara. Mistik Kejawen: Sinkretisme, Simbolisme, dan Sufisme dalam Budaya Spiritual Jawa. Yogyakarta: Penerbit Narasi, 2003.

[4] Gusfahmi.. Pajak Menurut Syariah. Retrieved from http://kin.perpusnas.go.id/DisplayData.aspx?pId=9602\&pRegionCode=PRBNSSBY\&pC lientId=711\%0A, 2011. 
[5] A. Jarmiko. Tafsir Ajaran Serat Wedhatama. Yogyakarta: Pura Pustaka, 2005.

[6] Kamaruddin. "Dimensi Sila 'Ketuhanan Yang Maha Esa' dalam Perspektif HAM Islam". In Right Jurnal Agama dan Hak Azazi Manusia, Vol. 3, No. 1, 2013.

[7] M. Kasim. "Falsafah Hidup Jawa dalam Naskah Sanguloro". Jurnal Lektur Keagamaan, Vol. 10, No. 2, pp. 301-320, 2012.

[8] K. Krippendorff. Content Analysis: An Introduction to Its Methodology. California: Sage Publications, 2018.

[9] J. Lantowa, N. M. Marahayu, and M. Khairussibyan. Semiotika: Teori, Metode, dan Penerapannya dalam Penelitian Sastra. Yogyakarta: Deepublish, 2017.

[10] R. Listyarti. Pendidikan Karakter dalam Metode Aktif, Inovatif, dan Kreatif. Jakarta: Penerbit Erlangga, 2012.

[11] S. Muhammad. Ritual dan Tradisi Islam Jawa. Yogyakarta: Narasi, 2010.

[12] S. Mujtaba. Ilmu Fiqh: Sebuah Pengantar. Retrieved from http://opac.iainjember.ac.id:80/index.php?p=show_detail\&id=12029, 2013.

[13] A. Muzakki. Urgensi Semiotika dalam Memahami Bahasa Agama. LiNGUA: Jurnal Ilmu Bahasa Dan Sastra, Vol. 3, No. 2, 2011.

[14] D. Nurrachman. "Teks Sastra Dalam Perspektif Semiotika Pragmatis Charles Sanders Peirce". Al-Tsaqafa: Jurnal Ilmiah Peradaban Islam, Vol. 14, No. 1, pp. 83-88, 2017.

[15] N. Rafiatun and N. Rafiatun. "Nilai Pendidikan Islam dalam Kesenian Tembang Macapat Islamic Values in the Art of Macapat Song". Jurnal Studi Agama, Vol. 17, No. 2, pp. 379-400, 2018.

[16] R. Ratih. Teori dan Aplikasi Semiotik Michael Riffaterre. Yogyakarta: Pustaka Pelajar, 2016.

[17] N. K. Ratna. Sastra dan Cultural Studies: Representasi Fiksi dan Fakta. Yogyakarta: Pustaka Pelajar, 2007.

[18] P. Santosa. Metodologi Penelitian Sastra: Paradigma, Proposal, Pelaporan, dan Penerapan. Yogyakarta: Azza Grafika, 2015.

[19] A. Skerrett. "Religious Literacies in A Secular Literacy Classroom". Reading Research Quarterly, Vol. 49, No. 2, pp. 233-250, 2014.

[20] Sukirno. "Studying Pitutur Luhur Teaching and Learning". Pendidikan Karakter, Vol. 1, pp. 108-114, 2013.

[21] I. Sutardjo. Kajian Budaya jawa. Surakarta: Jurusan Sastra Daerah, Fakultas Sastra dan Seni Rupa, Universitas Sebelas Maret, 2008.

[22] Y. Suwanto. and E. T. Winarni. "Sasmita Tembang Macapat (Suatu Kajian Pragmatik)". Prosiding Prasasti, pp. 284-290, 2016.

[23] M. H. Yana. Falsafah dan Pandangan Hidup Orang Jawa. Yogyakarta: Bintang Cemerlang, 2012.

[24] K. Saddhono and S. Supeni. "The role of dutch colonialism in the political life of Mataram dynasty: A case study of the manuscript of Babad Tanah Jawi." Asian Soc. Sci. vol. 10 no.15 pp. 1-7, 2014 